\title{
Uczestniczki i uczestnicy procesu kształcenia wobec wyzwań kształcenia zdalnego
}

\section{KEYWORDS}

distance learning

\begin{abstract}
Maria Porzucek-Miśkiewicz, Uczestniczki i uczestnicy procesu kształcenia wobec wyzwań kształcenia zdalnego [Participants of the education process in the face of remote education challenges]. Kultura - Społeczeństwo - Edukacja nr 2(20) 2021, Poznań 2021, pp. 141-155, Adam Mickiewicz University Press. ISSN 2300-0422, ISSN (Online) 2719-2717. DOI 10.14746/kse.2021.20.8

The article presents the results of study on the challenges faced by distance learning. It was carried out by means of a proprietary online questionnaire among students of pedagogy of the Faculty of Educational Studies at the University of Adam Mickiewicz in Poznań. Conclusions drawn on the basic research results may be helpful in understanding the well-being of students during distance learning.
\end{abstract}

Przed nauczycielkami i nauczycielami wiosną 2020 roku postawiono nowe nieoczekiwane zawodowe wyzwanie, a mianowicie organizację nauczania i uczenia $\mathrm{w}$ formie zdalnej. W wyniku wybuchu epidemii wywołanej wirusem SARS-CoV-2 w marcu po zawieszeniu stacjonarnej działalności dydaktycznej kształcenie na wszystkich szczeblach przeniosło się do sfery wirtualnej. Rozważania zawarte $\mathrm{w}$ artykule są wynikiem refleksji nad obrazem kształcenia zdalnego oraz inspiracji zaczerpniętych $\mathrm{z}$ raportów i prac specjalistek, specjalistów w tej dziedzinie, uzupełnionych o doświadczenia studentek i studentów stacjonarnych pierwszego roku pedagogiki Wydziału Studiów Edukacyjnych Uniwersytetu im. Adama Mickiewicza w Poznaniu.

* ORCID: https://orcid.org/0000-0003-4769-2115. 
Sytuacja, w której znalazły się polskie szkoły, zmieniła się w kryzysową. Edukacja zdalna pozostająca jeszcze do niedawna kwestią wyboru - stała się obowiązkiem. W kryzysowej edukacji zdalnej, poza kształceniem i realizacją podstawy programowej, ważny okazał się kontekst zdrowia psychicznego dzieci i młodzieży. Choć można uznać, że po czasie pozornie oswoiliśmy się z zaistniałą sytuacją, to zamknięcie szkół ocenione zostało przez uczestniczki i uczestników procesu kształcenia jako źródło stresu.

W obszarze szkolnej pomocy psychologiczno-pedagogicznej zostały przeorganizowane formy i zasady udzielania wsparcia w czasie pandemii. Jedna $\mathrm{z}$ trudności wynikała $z$ tego, iż praca pedagogów i psychologów ma przecież charakter oparty na bezpośrednim kontakcie z drugą osobą. Także takie założenia jak budowanie relacji na odczytywaniu sygnałów pozawerbalnych, dyskrecji i zaufaniu zostały utrudnione. Rolą szkolnych specjalistów w czasie pandemii było przede wszystkim pozostawanie $\mathrm{w}$ stałym kontakcie $\mathrm{z}$ uczennicami i uczniami. Istotna również okazała się regularność tych kontaktów oraz wymiana informacji pomiędzy pedagogami a rodzicami, prawnymi opiekunami, opiekunkami, nauczycielkami i nauczycielami.

W sytuacji nowej dominowały alternatywne do rozmowy bezpośredniej sposoby kontaktu. Pomoc organizowano w formie rozmowy telefonicznej czy dialogu za pośrednictwem komunikatora. W działaniach szkolnego pedagoga nie mogło także zabraknąć aktualnej informacji o godzinach do dyspozycji czy udostępnienia numeru telefonu dla potrzebujących. Jako przykład dobrych praktyk można podać opracowanie przez szkolnych specjalistów - pedagoga i psychologa szkolnego - planu działania kryzysowego, nazwanego Szkolną Grupą Pozytywnego Myślenia, proponującego uczniom dzielenie się dobrą energią, dodającego otuchy w nowej rzeczywistości edukacyjnej (Topolska, 2020).

W trakcie pandemii wszystkich uczestniczących w procesie kształcenia obok sukcesów - dosięgały także kryzysy, niedogodności, problemy. W związku z powyższym należało zintensyfikować działania wspierające. K. Topolska (2020) sugeruje, iż w świadczeniu pomocy psychologiczno-pedagogicznej nie tyle chodzi o rozwiązanie sytuacji problemowej, bowiem nie zawsze mamy na nią wpływ. Istotne jest to, by zmienić schematy myślenia, żeby nadać odmienne znaczenie przeżywanym stanom oraz nauczyć się je akceptować. Warto odrzucić utarte schematy, proponować uczniom, uczennicom, studentkom i studentom zainteresowanie, uważność oraz wyzwalać w nich kreatywność i twórczość.

Poza trudnościami natury technicznej pojawiały się także te dotykające sfery społecznej, emocjonalnej, poznawczej, psychicznej. Obciążenia dotyczyły uczennic i uczniów, studentek, studentów, rodziców oraz nauczycielek i nauczycieli. 
Opisując klimat e-szkoły, należy uwzględnić szerokie tło psychospołeczne. Uczennice i uczniowie pozostawali na długie miesiące w izolacji, nierzadko ze strachem o zdrowie i życie własne oraz osób z najbliższego otoczenia. Zostały zabronione lub ograniczone bezpośrednie spotkania międzyludzkie - $\mathrm{z}$ rówieśnikami, z nauczycielami - tak ważne dla harmonijnego rozwoju. Innym psychologicznym skutkiem tej sytuacji kryzysowej była utrata poczucia bezpieczeństwa. Młodzi ludzie podczas pandemii przeżywali tęsknotę za rówieśnikami, lęk, samotność, poczucie braku wpływu na sytuację, zmęczenie, przeciążenie. Dodatkowo doszło do sytuacji, w której gromadziły się negatywne emocje związane z pobytem w miejscu zamieszkania, a co za tym idzie brakiem możliwości ich rozładowania, wynikające z zakazu czy ograniczenia wyjść z domu, braku możliwości zmiany środowiska.

Podczas zdalnej edukacji, a także po powrocie do szkół, potrzebne było wnikliwe zainteresowanie, empatia oraz pozytywna energia, by uczestniczki i uczestnicy procesu kształcenia ponownie mogli zbliżyć się do siebie emocjonalnie, by budowali lub odbudowywali wzajemne relacje. Bez wątpienia w edukacji zdalnej, praktykowanej we wszystkich polskich szkołach w związku z pandemią koronawirusa, upatrywać można szereg wyzwań, zagrożeń, szans dla rozwoju oraz funkcjonowania młodych uczących się ludzi.

$\mathrm{Na}$ początku warto wyjaśnić pojęcie kształcenia zdalnego. Według Natalii Walter jest to „taka organizacja procesu nauczania-uczenia się, w której uczeń samodzielnie, w stosownym dla siebie miejscu, czasie i tempie, realizuje ustalony program nauczania. Instytucja edukacyjna (np. uczelnia) dostarcza potrzebnych materiałów, niezbędnych w osiąganiu wyznaczonych efektów kształcenia" (Walter, 2012: 225). W takim kształceniu nauczycielka bądź nauczyciel mają za zadanie wspierać aktywność jednostki uczącej się na odległość. Dzięki Internetowi są nie tylko udostępniane informacje, ale też odbywa się pełne komunikowanie oraz współdziałanie uczennic i uczniów (Walter, 2012).

Jak zauważa Mariusz Przybyła: „kształcenie zdalne otwiera zupełnie nowe zakresy edukacyjnej interakcji. Daje możliwości masowego, zespołowego, ale jednocześnie indywidualnego kształcenia w trybie synchronicznym i asynchronicznym. Warto zwracać na to uwagę, pozostawiając swobodę wyboru metod, form, środków nauczycielom oraz częstotliwości uczniom” (Przybyła, 2020: 215).

E-learning utożsamiany z technologiami informacyjno-komunikacyjnymi jest integralną częścią kształcenia zogniskowanego wokół nauczyciela, nauczycielki, ucznia, uczennicy, przedmiotu kształcenia i środowiska. Proces nauczania-uczenia się uwarunkowany jest wieloma kwestiami. Między innymi sposobem patrzenia na uczennicę, ucznia, podejściem do zmian w jego osobowości, co z kolei wpływa na tworzenie przestrzeni e-learningu, organizowanie całego procesu kształcenia. 
Warto podkreślić, iż e-learning umożliwia uznawanie indywidualnych preferencji uczennic i uczniów, choćby ze względu na elastyczność procesu kształcenia w takim trybie (Walter, 2013).

Z badań przeprowadzonych przez Danutę Morańską wynika między innymi, że polskie uczennice i uczniowie w badaniach międzynarodowych uzyskują niezadowalające wyniki w zakresie kompetencji związanych z codziennym funkcjonowaniem w społeczeństwie informacyjnym. Na podstawie wyników wieloletnich badań autorka podkreśla, iż konieczna jest zmiana relacji między uczniem a nauczycielem z mistrz - uczeń na organizator sytuacji edukacyjnych - aktywny uczeń, który współpracuje z innymi uczestnikami procesu kształcenia, poszukuje rozwiązań problemów, korzysta z różnych źródeł informacji oraz co ważne - potrafi działać zarówno świecie realnym, jak i wirtualnym. Zatem istnieje potrzeba systematycznego kształcenia nauczycielek, nauczycieli w celu doskonalenia własnego warsztatu, wzbudzania w uczennicach i uczniach motywacji oraz kształtowania pozytywnych postaw wobec procesu nauczania-uczenia się (Morańska, 2017). Istotne jest „kształtowanie umiejętności rozumienia mediów cyfrowych oraz cyfrowa alfabetyzacja, a także wzmocnienie umiejętności radzenia sobie ze stresem i sytuacjami trudnymi” (Łukasik, Jagielska, Mróz, Koperna, 2020: 53).

Mimo licznych szkoleń, starań i prób dostosowania strategii edukacyjnych do wymagań społeczeństwa informacyjnego wciąż dostrzec można potrzebę większego zaangażowania nauczycielek i nauczycieli. Ta grupa zawodowa funkcjonowała przez ostatnie kilkanaście miesięcy w świecie zmiany i przyznaje, iż czuła się zagubiona, przepracowana, obciążona nadmiernym stresem.

Wsparcie dla osób organizujących proces kształcenia jest niezbędne, bowiem od ich samopoczucia zależy atmosfera, efektywność i wiele innych aspektów edukacji zdalnej. Mowa tutaj o pomocy na różnych płaszczyznach: makro (ministerstwo, organ prowadzący), wewnątrzszkolnej (dyrekcja, współpracownicy) oraz indywidualnej (dbałość o własne zdrowie psychiczne) (Ptaszek, Stunża, Pyżalski, Dębski, Bigaj, 2020).

Marcin Zaród podpowiada gronu pedagogicznemu jak zadbać o swój dobrostan. Wśród propozycji znajdujemy - między innymi - sporządzenie planu dnia z zaznaczonymi granicami między pracą a czasem prywatnym, dla rodziny i siebie samego, $z$ asertywnym poinformowaniem innych o ich wyznaczeniu. Ponadto istotne będzie zaplanowanie czasu na ulubione czynności relaksacyjne. Autor zachęca, by w razie potrzeby nie wahać się zwrócić o pomoc do specjalistów, gdyż poza uczennicami i uczniami także obciążeni nauczyciele i nauczycielki mogą wymagać zaopiekowania (Zaród, 2020). 
W literaturze przedmiotu dokładnie charakteryzowane jest wsparcie społeczne online. N. Walter akcentuje, że: „Internet stanowi przestrzeń aktywności prospołecznych, jest też miejscem wsparcia społecznego, które w niektórych sytuacjach pełni kluczową rolę w powrocie do dobrostanu psychicznego człowieka uwikłanego w trudne wydarzenie krytyczne. $Z$ tego też powodu, a także z uwagi na łatwy dostęp można zauważyć, że zainteresowanie wsparciem online nieustannie wzrasta" (Walter, 2016: 210). Autorka mówi dalej o Internecie jako przestrzeni, w której przejawia się wsparcie informacyjne, duchowe, emocjonalne, instrumentalne i materialne. Szukanie konkretnej formy wspomagania uzależnione będzie od sytuacji i potrzeb jednostki. Dzięki Internetowi uczymy się w ciągu życia, stąd jego rola edukacyjna. Poszukujemy wzmocnienia w sytuacji kryzysowej, ale także wymieniamy się doświadczeniami oraz służymy pomocą, jeśli udało nam się wyjść z sytuacji krytycznej. Można powiedzieć, że Internet niesie ze sobą funkcję wsparcia społecznego online, daje szansę na powrót do dobrostanu psychicznego, pełniąc jednocześnie rolę socjalizacyjną, kulturotwórczą, autokreacyjną.

Ponadto wśród cech wsparcia społecznego wymienia się tekstowość, różnorodność form, pośredniość oraz anonimowość. Znaczącą zaletą wsparcia udzielanego za pośrednictwem technologii informacyjno-komunikacyjnych jest jego dostępność. Osoby korzystające na co dzień z Internetu sięgają po wzmocnienie w sytuacjach trudnych czy traumatycznych, mimo braku bezpośredniości. Zdaniem $\mathrm{N}$. Walter w sytuacji problemowej nierzadko potrzebujemy wsparcia $\mathrm{w}$ wymiarze fizycznym, które nie jest dostępne $\mathrm{w}$ relacji online. Jednocześnie dzięki funkcji komunikacyjnej Internetu zyskujemy możliwość znalezienia osoby udzielającej bezpośredniego wsparcia. Właśnie tekstowy charakter wsparcia społecznego umożliwia omawianie emocji. Autorka zaznacza, iż badania nad komunikacją zapośredniczoną przez komputer wskazywały na jej ograniczony charakter, nie sprzyjała ona budowaniu intymności, otwartości, opisywała ją sztywność oraz uproszczenie. Okazuje się jednak, że konieczność wypowiadania się w pozbawionej aspektów pozawerbalnych formie tekstowej przyczyniła się do bardziej przemyślanego i przyjaznego wyrażania myśli. Spisywanie indywidualnej sytuacji stresowej ostatecznie sprzyjało lepszemu radzeniu sobie z problemem (Walter, 2016).

Jacek Pyżalski (2021) na podstawie przeglądu badań prowadzonych w czasie pandemii prezentuje swoiste problemy w obszarze zdrowia i dobrostanu dzieci i młodzieży uczącej się. U młodych ludzi pojawiały się takie dyskomfortowe stany, jak: występowanie nastroju depresyjnego (nawet do $40 \%$ badanych) oraz objawy somatyczne, w tym trudności w zasypianiu (60\% respondentów) czy bóle głowy, bóle brzucha. Dostrzec także można zmianę stylu życia u dzieci i młodzieży, lecz niestety częściej to przeobrażanie dotyczyło stylu antyzdrowotnego niż prozdro- 
wotnego. Zgodnie z autorem należy przyznać, iż wszystkie wymienione trudności wymagają działań profilaktycznych, terapeutycznych.

W kwestii oceny komunikacji w edukacji zdalnej warto odejść od myślenia w kategoriach gorszej jakości komunikacji zapośredniczonej. Obecnie podkreśla się bogactwo i otwartość tej formy. Trafnie oddają to słowa: „poprzez wybór narzędzi i tego, jak je stosujemy, to my regulujemy, na ile uda się być blisko z innymi ludźmi" (Pyżalski, Walter, 2020: 13).

Powszechnie wyczuwa się liczne obawy o jakość relacji międzyludzkich, o ich kondycję po długim funkcjonowaniu w izolacji od szkolnej codzienności, od rówieśników. Niezwykła mądrość, a jednocześnie zachęta płynie ze słów Tomasza Bilickiego - nauczyciela, interwenta kryzysowego: „Oparcie edukacji wyłącznie na podawaniu wiedzy jest w ogóle słabym pomysłem, bo znacząco redukuje rolę i nauczyciela, i ucznia. Uczeń nie jest pendrive’em, a nauczyciel gniazdem USB, które ma przepchnąć na tego pendrive’a jak największą ilości informacji. Edukacja zdalna jest trudna, to prawda, natomiast ja naprawdę nie mam poczucia, że rozmawiam z monitorem, kiedy prowadzę lekcję. Mam świadomość, że po drugiej stronie są żywi ludzie ze swoimi przeżyciami, emocjami, marzeniami. Podczas nauki zdalnej można te relacje i nawiązywać, i je pielęgnować. To kwestia wyłącznie kompetencji i przekonań nauczyciela. I jeśli ktoś wcześniej tego nie robił, może spróbować od zaraz" (Jucewicz, 2021).

Dobrze pozostać $\mathrm{z}$ perspektywą, że relacje będące $\mathrm{w}$ centrum edukacji tradycyjnej pozostaną $\mathrm{w}$ tym samym miejscu $\mathrm{w}$ edukacji zdalnej. $\mathrm{Z}$ kolei budowa ich w warunkach komunikacji zapośredniczonej z wypełnianiem luk, które niesie ewentualny brak bezpośredniego kontaktu stanowi prawdziwe wyzwanie (Pyżalski, Poleszak, 2020).

Autorka niniejszego artykułu przeprowadziła badania ${ }^{1}$, by poznać studenckie opinie na temat organizacji i przebiegu kształcenia zdalnego, dzięki którym prezentuje ogólny zarys perspektywy osób zaczynających dzienne studia pedagogiczne. Choć oczywistym jest, iż nie można zebranych wyników generalizować, to zebrane opinie mogą stanowić zalążek refleksji i punkt wyjścia do jej kontynuacji. Na podstawie wypowiedzi studentek i studentów zebranych w czerwcu 2021 roku można dokonać następujących spostrzeżeń.

\footnotetext{
${ }^{1}$ Badania własne, przeprowadzone przez autorkę na końcu semestru letniego roku akademickiego 2020/2021 wśród trzydziestu studentek i studentów pierwszego roku pedagogiki Wydziału Studiów Edukacyjnych Uniwersytetu im. Adama Mickiewicza w Poznaniu za pomocą anonimowego kwestionariusza zawierającego dwanaście pytań otwartych zogniskowanych tematycznie wokół kształcenia zdalnego.
} 
Wśród studenckich odpowiedzi na pytanie o to, co najbardziej podoba się im w studiowaniu zdalnym, dość mocno akcentowana była oszczędność czasu przeznaczonego niegdyś na dojazdy na uczelnię oraz brak problemów z dojazdem. Potwierdzają to słowa studentki: nie muszę spędzić całego dnia poza domem, więc mam więcej siły do pracy i nauki. Zyskanie dodatkowego czasu w ciągu dnia miało bezpośredni wpływ na poprawę jakości i częstości rodzinnych spotkań, studenci dostrzegali, że mogą odwiedzać częściej i na dłużej rodzinę. Dalej, co również wiąże się z nadwyżką czasu, wymieniano możliwość późniejszego wstawania, wolność w organizacji własnego czasu, wydłużenie snu, swobodę oraz wygodę ubioru, a także oszczędności finansowe wynikające $\mathrm{z}$ braku konieczności zakupu benzyny czy biletów na środki transportu. Aspekt ekonomiczny został także przywołany w odniesieniu do zastąpienia książek podręcznikami i lekturami w formie elektronicznej. Ta oszczędność finansowa miała niekiedy tak duże znaczenie, że nawet zaważyła na decyzji o podjęciu studiów: nie było mnie stać na to, żebym studiowała, ale zdecydowałam się na podjęcie nauki w szkole wyższej ze względu na pierwszy rok $w$ formie zdalnej i znalezienie pracy na miejscu $w$ rodzinnej miejscowości.

Były też głosy akcentujące większą niż zazwyczaj możliwość pogodzenia nauki z życiem codziennym. Wśród czynników związanych ze sferą dydaktyczną pojawiło się jeszcze wyraźne zadowolenie $\mathrm{z}$ faktu otrzymywania gotowych prezentacji czy nagrań nieobowiązkowych wykładów od prowadzących. Ze studenckich opinii wynikało, iż nie trzeba dużo pisać, bo większość materiałów jest udostępniana przez nauczycielki i nauczycieli akademickich. Zdalna organizacja kształcenia umożliwiła komuś pogodzenie dwóch kierunków na dwóch różnych wydziałach bez wychodzenia z domu. Oceniono, iż studiowanie online daje większy komfort psychiczny podczas egzaminów i zaliczeń, a niższy poziom stresu podczas studiowania zdalnego podkreślano wielokrotnie.

Nie bez znaczenia okazało się także miejsce nauki, gdyż podkreślano atuty znajdowania się w bezpiecznym miejscu. Studentka ujęła to następującymi słowami: na zajęciach siedze w swoim domu, w komfortowym dla mnie otoczeniu. Właśnie tej atmosferze zawdzięczano zwiększenie aktywności oraz skupienie uwagi na zajęciach, brak bodźców rozpraszających, przełamanie bariery komunikacyjnej i lęku przed ekspozycją publiczną, rozluźnienie, wygodne pozycje, jeśli istnieje potrzeba - na przykład przeciągnięcie się. Odnotowano także głos mówiący o zyskaniu możliwości regularnego spożywania posiłków podczas pobytu w domu. Ciekawe było ukazanie perspektywy rozwoju nowej pasji kulinarnej zbudowanej na bazie czasu pozyskanego z okienek i przerw między zajęciami. 
Ponadto w kształceniu zdalnym studentkom i studentom podoba się to, że mogą studiować $\mathrm{z}$ każdego miejsca, że mają więcej czasu dla siebie, podczas dużej przerwy czy okienka nie muszą szukać miejsca, gdzie musieliby czekać, jak w przypadku zajęć stacjonarnych. Nie bez znaczenia okazało się łatwiejsze pogodzenie pracy ze studiami.

Ważne dla studiujących okazało się pozostawienie wolności wyboru w kwestii odsłony kamery podczas zajęć. Podkreślają oni, że mieli możliwość, by nie ukazywać własnego wizerunku w przypadku słabszego dnia czy gorszego samopoczucia. $\mathrm{W}$ związku $\mathrm{z}$ tym chwalono także możliwość uczestniczenia $\mathrm{w}$ zajęciach nawet podczas choroby.

Następnie studentki i studentów zapytano o to, jakie formy i metody kształcenia odpowiadają im najbardziej na zajęciach zdalnych. Zdecydowanie największą popularnością cieszyła się organizacja zajęć z podziałem na małe zespoły, ze wskazaniem, by również grupa mogła zaproponować interesujące zagadnienia, by nie zawsze były one narzucone przez osobę prowadzącą. Jedna studentka przyznaje, że docenia pracę zespołową, pod warunkiem, że uczestnicy sami dobierają się w grupy, bo choć ona dużo mówi i ma spore poczucie obowiązku oraz chęci do angażowania się, to zdarza się, że trafia na osoby, które nie chcą się odzywać, nie chcą współpracować i na nią spada cała odpowiedzialność. Sytuację taką ocenia jako irytującą, z którą nie wie jak sobie poradzić, zwłaszcza jeśli dana grupa jest wyznaczona na stałe do pracy.

Spośród metod nauczania studenckie preferencje koncentrują się wokół dyskusji i luźnej pogadanki. Studentkom i studentom odpowiada także praca $\mathrm{z}$ tekstem. Zauważyć można, że lubią pisanie esejów, które jest zdecydowanie wyżej i bardziej twórczo oceniane niż dla przykładu pisanie testów. Jeśli chodzi o prezentacje, to jako odbiorcy wymagają, by była ona dobrze widoczna oraz omawiana w sposób spokojny tak, by słuchający zdążyli notować. Młodzi ludzie przyznają, że ważna jest atmosfera zajęć, która sprawia, że pojawia się chęć i motywacja do aktywnego zaangażowania się i wypowiadania. Lubią, gdy wykładający jasno stawia swoje wymagania oraz wyraźnie akcentuje, co w danym bloku zagadnień jest ważne. Oprócz rozmów i wzajemnej wymiany doświadczeń, które jak zaakcentowano są bardzo ważne w trakcie izolacji, dużym zainteresowaniem cieszy się film dydaktyczny.

Studentki i studenci pierwszego roku podjęli próbę zdefiniowania kształcenia zdalnego i zaproponowali własne robocze ujęcia:

- Kształcenie zdalne to takie w przypadku którego wszystkie osoby uczestniczące $w$ procesie kształcenia przebywają w różnych miejscach i komunikują się za pomoca jakichś narzędzi jak np. Teams albo Moodle. 
- Bezkontaktowe nauczanie z wykorzystaniem nowych technologii.

- Sytuacja, kiedy proces kształcenia nie jest prowadzony „twarza w twarz”, kształcenie na odległość.

- Kształcenie o każdej porze i w jakim miejscu tylko chcesz.

- Nauczanie i uczenie się przy pomocy urządzeń elektronicznych, gdzie kontakt ucznia z nauczycielem odbywa się przez różne platformy i programy.

Nie zabrakło także krytycznych spojrzeń o zabarwieniu negatywnym:

- Jest to zdecydowanie wygodniejsza forma nauczania dla osób, które nie lubia wychodzić $z$ domu. Powoduje niestety stres zwiąany ze sprzętem, nad którym nie zawsze możemy zapanować.

- Nauczanie wirtualne ogranicza do minimum kontakty międzyludzkie.

- Kształcenie zdalne jest to forma nauczania-uczenia się, która wymaga od uczniów i nauczycieli większego zaangażowania w zajęcia i rozwijania umiejętności samokształcenia.

- Nie daje rzetelnej wiedzy, ponieważ o wiele łatwiej jest ściagać przez co szanse nie sa wyrównane. Zdają ci, co ściagali i to na lepsze wyniki niż ci, którzy faktycznie się do tej nauki przyłożyli.

Warto do tego zbioru wypowiedzi jeszcze dodać dwie oddające w pełni klimat minionych dziesięciu miesięcy studiowania, a mianowicie:

- Halo, czy mnie widać, czy mnie stychać?

- Nauczanie zdalne - jazda bez trzymanki.

Nie wszyscy jednak wychodzą z roku kształcenia online z zadowoleniem, bowiem wśród określeń pojawiło się też takie: Niby kształcenie, ale jednak jakaś ułomna jego forma.

Studentki i studentów pedagogiki zapytano o to, czego oczekują od e-nauczycielki, e-nauczyciela. Okazuje się, że studiujący na odległość w izolacji od rówieśników najbardziej potrzebują wyrozumiałości, także cierpliwości, zaangażowania i dostępności. Mówią też o dobrej atmosferze na zajęciach, zaufaniu do grupy, chęci do uczenia się nowych rzeczy, otwartości i oczywiście wiedzy na temat wykładanego przedmiotu. Ponadto dla młodych liczy się szczegółowe tłumaczenie oraz przejrzyste przekazywanie treści nauczania.

Bardzo często podkreślano wzajemne zrozumienie w kwestii trudności ze sprzętem, Internetem, jakością połączenia, brakiem prądu, wszelkimi problemami technicznymi. Niezwykle ważne jest dla osób, które studiują i mają różny poziom możliwości to, by nie skracać czasu na rozwiązywanie zadań tylko dlatego, że test jest $\mathrm{w}$ formie zdalnej, być może $\mathrm{w}$ obawie przed ściąganiem. Najlepiej to, czego oczekuje student od nauczycielki, nauczyciela akademickiego pracującego online, oddadzą słowa jednego z nich: tak naprawdę tego samego, czego przy kształceniu 
stacjonarnym, odrobiny zrozumienia, szczególnie w kwestii problemów technicznych, szczególnie jeśli zdarzaja się rzadko.

Pojawiła się pozytywna opinia podsumowująca dwa ostatnie semestry pracy, mówiąca o tym, iż nauczyciele dobrze sprawdzili się podczas pracy zdalnej, niewiele by można oczekiwać.

Wśród największych trudności w kształceniu zdalnym z perspektywy studentek i studentów pierwszego roku pedagogiki wymienić można brak bezpośredniego kontaktu z drugim człowiekiem, kontaktu twarzą w twarz z innymi, z koleżankami, kolegami, z prowadzącymi zajęcia. Osoby te nie miały nigdy dotąd okazji zobaczyć się w rzeczywistości pozawirtualnej, stąd też może wynikać dyskomfort, o którym wspomina jedna ze studentek: wypowiadanie się przed grupa osób, których nie znam jest dla mnie znacznie trudniejsze podczas zajęć zdalnych niż stacjonarnych.

Ponadto nauki nie ułatwiała ogromna ilość rozpraszaczy, kłopoty z koncentracją i zapamiętywaniem. Towarzyszyła im mniejsza motywacja do nauki oraz początkowe trudności ze zmianą harmonogramu swojego dnia. Wyzwaniem było samo przyzwyczajenie się do tej formy kształcenia, bowiem motywacja spadła, a zmiana harmonogramu dnia stanowiła pewnego rodzaju niedogodność. Jako uciążliwe opisane zostały męczące, długie godziny spędzone przed komputerem: po zajęciach oczy i kręgosłup nie wytrzymuja.

Student tak opisuje zmiany, które zaszły podczas minionych miesięcy: Dom zawsze był dla mnie miejscem odpoczynku. W czasie pandemii mój pokój stat się gabinetem, sypialniq i jadalniq. W tym pokoju dzieje się wszystko i nie mam okazji odpoczać. Kolejna osoba podkreśla, iż w pracy zdalnej przeszkadzało jej to, że dom musiał zmienić swoje zadanie, zatarła się granica pozwalająca zachować podział na odpoczynek w domu, a pracę w szkole. Z kolei inna studentka opisuje trudności związane z zamieszkaniem w miejscu, gdzie prawie nie ma zasięgu, w związku z czym na większości zajęć miała problemy techniczne, a jedynym rozwiązaniem byłaby wyprowadzka.

Niewątpliwie można powiedzieć, że zdaniem badanych studentek, studentów okres zamknięcia i izolacji społecznej ocenić można jako kryzysowy. W odpowiedzi na pytanie o to, jakie kryzysy pojawiały się podczas nauki zdalnej, pada wiele smutnych wyznań. Niepokojące jest nagromadzenie myśli rezygnacyjnych w związku z obciążeniem obowiązkami i poczuciem samotności wobec nich. Studentki i studenci mówią wprost o chęci rzucenia studiów w trakcie roku zdalnego. U studiujących pojawiały się myśli typu: to nie dla mnie, ja się nie nadaję, myślałam, że do niczego się nie nadaję i nie zdam czy miałam wrażenie, że nic nie ogarniam. 
Stany lękowe, stres, chwiejne emocje, częste załamania nerwowe, o których wspominają, przeplatały się ze spadkiem motywacji do pracy, niechęcią do nauki. Momentami przerastał ich nadmiar materiału, pojawiały się problemy ze zrozumieniem przekazywanego tekstu, znudzenie, zmęczenie oraz poczucie przytłoczenia obowiązkami. Tylko jedna osoba wspomniała o lenistwie.

Studentka będąca w kryzysie w związku z pogorszeniem stanu zdrowia psychicznego opisuje swój stan następująco: większość kryzysów wynikała z prywatnych problemów także w sferze zdrowia psychicznego, co powodowało $z$ kolei zaległości $w$ nauce, $w$ oddawaniu prac na czas. Spotkałam się z dużym zrozumieniem. Jak już wcześniej wspomniano, przez cały czas trwania edukacji zdalnej pojawiał się niepokój spowodowany czynnikami niezależnymi od studentek i studentów, były to kryzysy związane z zakłóceniami technicznymi i poczuciem bezradności wobec nich. Dla przykładu pojawiał się stres, że na jakimś egzaminie może dojść do przerwania połączenia.

Osoby studiujące na pierwszym roku pedagogiki na Uniwersytecie im. Adama Mickiewicza w Poznaniu zapytano czy wiedzą, gdzie mogą się zwrócić po wsparcie w razie kryzysu w trakcie kształcenia zdalnego. Okazuje się, że tylko połowa z pytanych wiedziała, gdzie uzyskać wsparcie w sytuacji trudnej. Poza profesjonalnym wsparciem psychologicznym na uniwersytecie z dostępnymi dla każdego dyżurami psychologów i psycholożek wymieniano także wykładowców, pracowników uczelni jako osoby godne zaufania. Istotne dla studentek i studentów było także wsparcie przyjaciół i rodziny oraz korzystanie z terapii.

Do osób kończących pierwszy rok studiów skierowano pytanie o to, czego najbardziej brakuje im w kształceniu zdalnym. Zdecydowana większość z nich przyznała, że ludzi, kontaktu z ludźmi, kontaktu ze znajomymi, kontaktu z drugim człowiekiem, kontaktu z rówieśnikami, bezpośredniego kontaktu z grupą i wykładowcami. Studenci akcentowali ponownie, że od niektórych wykładających oczekują wyrozumiałości, a od osób ze swojej grupy zajęciowej - współpracy. W wypowiedziach wyczuwa się tęsknotę za rzeczywistością sprzed pandemii, czytamy, iż brakuje zadań, które byśmy mogli wspólnie wykonywać na świeżym powietrzu oraz inna osoba dodaje: niczego, chciałbym w końcu zobaczyć uczelnię, poznać osoby, $z$ którymi studiuję oraz wykładowców. Ktoś jeszcze dodaje, że brakuje mu płynnego komunikowani się z innymi. Gdyby wszyscy mieli sprawny Internet i sprzęt to nauczanie zdalne by było dla mnie bez wad.

Kolejnym etapem było sprawdzenie jak wygląda organizacja nauki online oraz czy studentki i studenci mają jakieś własne wypróbowane sposoby. Większość z nich podkreślała, że uczą się tak, jak niegdyś stacjonarnie. Uczęszczają na zajęcia, notują, a potem się uczą. Dodatkowo zapisują datę zaliczenia i rozplanowują, kiedy 
czego się będą uczyć czy pisać, by oddać prace w spokoju przed czasem. Drukują sporządzone notatki, powtarzają, podkreślają. Student wyjawił, że stara się wykonywać wszystkie zadania z dnia na dzień, by nie odkładać niczego na później, zapisywać wszystkie zadania na dany tydzień, by czegoś nie przeoczyć. Studentka prowadzi zeszyt zadań do wykonania, skreśla obowiązki, co przybliża ją do wolnych chwil. Ktoś inny oznajmił, że bierze notatki i próbuje się zmusić do nauki. Są osoby, które trzymają się konkretnego planu dnia: po zajęciach robię sobie dwugodzinna przerwę na inne obowiąki, potem zabieram się do zadań wyznaczonych przez nauczycieli a na koniec dnia czytam zadane lektury. Ponadto pojawiły się takie sposoby, jak zrobienie własnego kalendarza i zapisywanie najważniejszych informacji, robienie fiszek z zagadnieniami, powtórki w trakcie weekendu oraz utrzymywanie porządku w miejscu pracy. Godne podkreślenia są trzy rozwiązania poprawiające komfort i samopoczucie:

1. Staram się wyznaczać czas na pracę oraz na życie prywatne.

2. Często zmieniam pokoje, w których się uczę, żeby mój pokój nie kojarzył mi się wyłacznie z nauka i przymusem.

3. Gdy tylko mogę wychodzę się przewietrzyć.

Skuteczne rozwiązanie na motywację do pracy znalazł student stwierdzający: pomaga mi to, że mieszkam z dziewczyna i zazwyczaj siadamy do nauki razem, bo motywujemy się wzajemnie. Mam też aplikację Forest, która powstrzymuje mnie od ruszania telefonu, kiedy mam sięuczyć. Pomaga mi też robienie rozpisek, co mam do zrobienia na następny tydzień.

Pierwszorocznym pozwolono rozbudzić wyobraźnię i postawiono przed nimi pytanie, co by uczyniło studiowanie zdalne lepszym. Zebrano takie odpowiedzi, jak: większe zrozumienie studentów, w miarę możliwości indywidualne podejście do studenta, różnorodność zadań, ciekawsze formy zaliczenia, np. eseje, większa swoboda, mniejsze sprawdzanie wiedzy poprzez testy, omawianie zagadnień ściśle związanych z daną specjalnością. Ponadto ulepszanie platform, nauczanie hybrydowe oraz dobry Internet i sprzęt.

Ktoś inny słusznie proponuje: możliwość spotkania się z grupa co jakiś czas na osobnym kanale i poznawanie siebie nawzajem bez przymusu, lecz z własnych chęci. Dobrym podsumowaniem niech będą słowa studentki: Nic nie zastąi kontaktu $z$ drugim człowiekiem.

Jeden głos był pochwałą zajęć organizowanych na pierwszym roku pedagogiki i miał taki wydźwięk: myślę, że studiowanie zdalne, którego doświadczyłem było zorganizowane na dobrym poziomie.

Na samym końcu zapytano studiujących, czego nowego dowiedzieli się o sobie w czasie trwania kształcenia zdalnego. Wielu przyznało, że się przez ten rok wzmocniło. Pojawiły się następujące wypowiedzi: 
- mimo trudnych momentów poradzę sobie;

- umiem sobie poradzić nawet, jeśli zostanę sama;

- okazuje się, że potrafię dość dobrze radzić sobie z planowaniem czasu wolnego;

- przestałam bać się odzywać w różnych dyskusjach, ludzie nie widząc mnie nie oceniaja mojego wygladu a jedynie moje słowa;

- dowiedziałam się, że nie jestem taka nieśmiała jak sądziłam dotą;

- może nie tyle o sobie, ale o swojej grupie, że mimo ciężkich sytuacji wspieramy się i próbujemy razem uczyć się po zajęciach na platformie MS Teams.

Jak wynika z wypowiedzi studentki, był to czas szczególny. Oto jak go opisuje: Odkryłam, że uwielbiam dyskutować, pisać eseje i że bardzo interesuja mnie badania. W sumie czas od rozpoczęcia pandemii był dla mnie bardzo ważny. Odkryłam wiele rzeczy w sobie dotyczacych tego, kim jestem. Znalazłam pomysł na siebie, bo $z$ decydowałam, że chcę studiować i studiować i studiować, aż uda mi się zrobić doktorat a wtedy wykładać i robić własne badania.

Pośród skutków negatywnych przebywania w domu wystąpiło rozleniwienie, przekonanie, że taki typ nauki nie jest dla danej osoby, zmęczenie dłuższym siedzeniem w jednym miejscu, przekonanie o braku samodyscypliny. Pojawił się też opis stanów, które wymagają wsparcia. Między innymi była mowa o nieradzeniu sobie ze stresem, o uzyskaniu wiedzy że można mieć kilka załamań nerwowych dziennie. Dobrym podsumowaniem tego wątku będą słowa studentki podkreślające rolę wzajemnych spotkań w świecie realnym: dowiedziałam się jak cenne jest wychodzenie na uczelnię. Nauczyłam się również, że aby zdrowo funkcjonować potrzebuje kontaktu $z$ innymi osobami.

Na podstawie zebranego materiału można przyjąć, że studiowanie online daje studentkom i studentom pewnego rodzaju komfort psychiczny, podkreślono jego liczne walory, w tym: znajdowanie się w bezpiecznym miejscu, dostęp niezależnie od lokalizacji, kondycji, stanu zdrowia czy aspektu finansowego. Okazuje się, iż od osób nauczających oczekuje się przede wszystkim wyrozumiałości. Studentkom i studentom najbardziej brakuje właśnie zrozumienia ze strony prowadzących oraz indywidualnego podejścia. Wśród form organizacyjnych kształcenia największą popularnością cieszy się nauczanie zespołowe, a wśród metod aktywizujące dyskusje oraz swobodne pogadanki. Jednakże nie brakuje ocen o zabarwieniu negatywnym. Odczuwane trudności dotyczą braku realnego kontaktu z drugim człowiekiem. Akcentowane jest także zatarcie się granicy między domem a uczelnią. Główne kryzysy zorientowane są wokół poczucia samotności, myśli rezygnacyjnych, stresu i lęku. Niepokojącym jest fakt, iż tylko połowa ankietowanych ma wiedzę do kogo na uczelni zwrócić się z prośbą o wsparcie. Podsumowując, można przyjąć, że w ogólnej ocenie kształcenie zdalne przyniosło jednostkom studiują- 
cym wiele korzyści, dało uczestnikom wiele wzmocnień, wykształciło zaradność, rozbudziło możliwość wzajemnego wspierania się w potrzebie.

$\mathrm{Z}$ minionego roku szkolnego i akademickiego wychodzimy bogatsi o nowe doświadczenia. Potwierdziło się przekonanie, iż świat wirtualny jest ważnym miejscem funkcjonowania, w którym możliwa jest dbałość o dobrą jakość kontaktów interpersonalnych, jest on częścią życia ludzi w różnym wieku (Andrzejewska, 2019). Niewątpliwie nowe edukacyjne warunki wymagały stworzenia nowatorskich form wsparcia, ale co ważne - kolejnymi krokami postawionymi przed gronem pedagogicznym była i nadal jest kontynuacja szeroko rozumianego wsparcia po pandemii. Z całą pewnością efekty zdalnej pracy pedagogicznej, dydaktycznej, wychowawczej, opiekuńczej pozostaną widoczne jeszcze długo po jej zakończeniu. Należy wciąż stawiać sobie pytanie, co zostanie z nami na dłużej, co podczas spotkań wirtualnych było na tyle ważne i skuteczne, by zostało uwzględnione w codziennych działaniach, co powinniśmy ze sobą zabrać w dalszą edukacyjną podróż.

\section{Bibliografia}

Andrzejewska A. (2019), Świat wirtualny miejscem nawiązywania i utrzymywania relacji przez młodzież, [w:] A. Wrońska, R. Lew-Starowicz, A. Rywczyńska (red.), Edukacja - relacja - zabawa. Wieloaspektowość internetu w wymiarze bezpieczeństwa dzieci i młodzieży, Warszawa, s. 68-89.

Jucewicz A. (2021), Tomasz Bilicki, nauczyciel: Dzieciaki nie chca wracać do szkót, zwyczajnie się nas boja. I maja powody, https://www.wysokieobcasy.pl/akcje-specjalne/7,174350,26938977,toma sz-bilicki-nauczyciel-dzieciaki-nie-chca-wracac-do.html, dostęp: 05.07.2021.

Łukasik J.M., Jagielska K., Mróz A., Koperna P. (red.) (2020), Młodzi nauczyciele o zdalnej edukacji w czasie COVID-19, [w:] N.G. Pikuła, K. Jagielska, J.M. Łukasik (red.), Wyzwania dla edukacji w sytuacji pandemii COVID-19, Kraków, s. 31-56.

Morańska D. (2017), Nauczyciel wobec wyzwań społecznego społeczeństwa informacyjnego, [w:] A. Iwanicka (red.), Edukacyjne i społeczne wyzwania rzeczywistości cyfrowej, Poznań, s. 45-54.

Przybyła M. (2020), Szkoła „złowiona” we własne sieci - rzecz o kształceniu tradycyjnym i komplementarnym w obliczu pandemii koronowirusa Covid-19, [w:] M. Christoph, S. Wawrzyniak (red.), Społeczno-edukacyjny potencjał szkoły a rynek pracy, Poznań, s. 211-222.

Ptaszek G., Stunża G.D., Pyżalski J., Dębski M., Bigaj M. (red.) (2020), Edukacja zdalna: co stało się z uczniami, ich rodzicami i nauczycielami?, Gdańsk.

Pyżalski J. (2021), Zdrowie psychiczne i dobrostan młodych ludzi w czasie pandemii COVID-19 przegląd najistotniejszych problemów, Dziecko Krzywdzone. Teoria, badania, praktyka, 20(2), s. $92-115$.

Pyżalski J., Poleszak W. (2020), Relacje przede wszystkim - nawet jeśli obecnie jedynie zapośredniczone, [w:] J. Pyżalski (red.), Edukacja w czasach pandemii wirusa COVID-19. Z dystansem o tym, co robimy obecnie jako nauczyciele, Warszawa, s. 28-36.

Pyżalski J., Walter N. (2020), Audyt pedagogiczno-technologiczny platform edukacyjnych firmy Learnetic, Poznań. 
Topolska K. (2020), Pomoc psychologiczno-pedagogiczna w czasie pandemii, https://epedagogika.pl/ zasady-i-zadania/pomoc-psychologicznopedagogiczna-w-czasie-pandemii-3602.html, dostęp: 21.06.2021.

Walter N. (2012), Obszary edukacyjnych zastosowań Internetu, Studia Edukacyjne, nr 23, s. 217-228.

Walter N. (2013), Pedagogika 2.0. O potrzebie kształcenia specjalistów z zakresu e-learningu, Neodidagmata, nr 35, s. 145-150.

Walter N. (2016), Internetowe wsparcie społeczne. Studium socjopedagogiczne, Poznań.

Zaród M. (2020), Jak nauczyciele moga obecnie zadbać o swój dobrostan? [w:] J. Pyżalski (red.), Edukacja w czasach pandemii wirusa COVID-19. Z dystansem o tym, co robimy obecnie jako nauczyciele, Warszawa, s. 81-85. 
